\title{
The Influence of Life Kinetic Training Method and Motor Educability on Improvement of Football Playing Performance
}

\author{
Komarudin Komarudin*, Yudi Nurcahya, Patriana Nurmansyah, Widi Kusumah \\ Pendidikan Kepelatihan Olahraga \\ Universitas Pendidikan Indonesia \\ Bandung, Indonesia \\ *komarudin_pko@upi.edu, udinurcahya@upi.edu,Patriananurmansyah@upi.edu, widikusumah@upi.edu
}

\begin{abstract}
This study aims to examine the differences in the effect of the Life Kinetic and Conventional Training methods on improving soccer playing performance, to determine the interaction effect of the Life Kinetic training method and conventional methods and motor educability on improving soccer playing performance and to examine the differences in performance in playing football between athletes trained with the Life Kinetic training method and conventional training in the high motor educability and low motor educability groups. In this study used an experimental method for 40 UPI soccer athletes taken through random assignment techniques based on high and low motor educability levels. The results showed that there are no differences in the effect of Life Kinetic training and conventional training on improving soccer playing performance. The results also showed that there are no differences in the performance of playing soccer between athletes trained with the Life Kinetic training method and conventional training in the high motor educability and low motor educability groups. This is because during the Life Kinetic training the athletes try to combine three forms of complex training, namely motor activity, cognitive challenges, and visual perception.
\end{abstract}

Keywords: football performance, life kinetic, motor educability

\section{INTRODUCTION}

Football athletes in displaying their performance must be supported by several abilities including physical, technical, tactic, and mental abilities [1], because these abilities are one of the predictors of athlete success [2]. Mastery of physical abilities, techniques, and tactics is needed so that athletes perform optimally and are skilled at moving in sports and are more efficient at moving. While mental abilities are needed so that athletes are ready to face various challenges and obstacles during the process of training and competition, so that all the potential possessed by athletes can be displayed to the maximum $[3,4]$.

Reflecting on football in European countries the physical conditions of training are already so advanced and very varied supported by technology and the quality of qualified players to perform well [5]. The process of training in the country in addition to training to improve the basic physical components also combine it with cognitive motor coordination training methods or known as the Life Kinetic training method. So no wonder the majority of foreign athletes when faced with complex problems on the field, athletes are still able to display good playing performance and be able to overcome and make decisions quickly on every opportunity they get.

Indonesian soccer athletes do face many obstacles, including those related to the quality of players in displaying playing performance. The playing style of Indonesian athletes is different from that of foreign athletes who are more disciplined in positions and more tactical [6]. The low quality of playing in Indonesian soccer athletes may be due to the fact that the training process in Indonesia has not been maximized, especially in the critical analysis of the youth program, and neglecting motor skills and cognitive training at young age [5], such cognitive training methods include Life training Kinetic This exercise in Europe has become a routine training method by soccer athletes, because soccer athletes are required to have the ability to have physical conditions, cognitive functions, in addition to having the ability to master the techniques of their sport branches.

Facts on the field most soccer athletes have difficulty playing with effective and efficient motion when competing so that athletes lack good playing skills which are shown to be more tactical with good kick and shot accuracy, so it does not hit the expected target, as a result the target is not achieved [7]. Life Kinetic training methods will greatly help soccer athletes because they will be able to form the ability of coordination, agility, and cognitive functions that will contribute to improving the performance of playing football. Suspected to have good motor educability capabilities.

In the Life Kinetic method is closely related to the ability of motor educability, because in motor educability has the motor intelligence function because there is a process of remembering, thinking, analysing, as well as demonstrating the movements required by athletes in playing football. The term motor educability to indicate this type of motor intelligence [8]. In football, cognitive ability is very important because athletes must be able to make split-second decisions under pressure, or memorizing complex movement sequences that they have learned [9]. In Life Kinetic training athletes must be able to 
(The Games Performance Assessment Instrument) [16]. This instrument includes five components, namely decisions made, skill execution, support, adjust, and game performance (GP). This instrument has a validity of 0.82 and reliability of 0.90 .

\section{RESULTS AND DISCUSSION}

Data collected through the measurement process, then processed, analysed and interpreted by using a statistical approach. The data analysed in this study are the results of the ability to play soccer skills.

Furthermore, to see an increase in the score of the results of the alert test and the final test is done by reducing the results of the final test with the initial test. The results of the reduction between tests are called increase scores or score differences. An explanation of the difference in score between the initial test results and the final test results on the Life Kinetic and Motor Educability training methods can be seen in figure 1 and figure 2 .

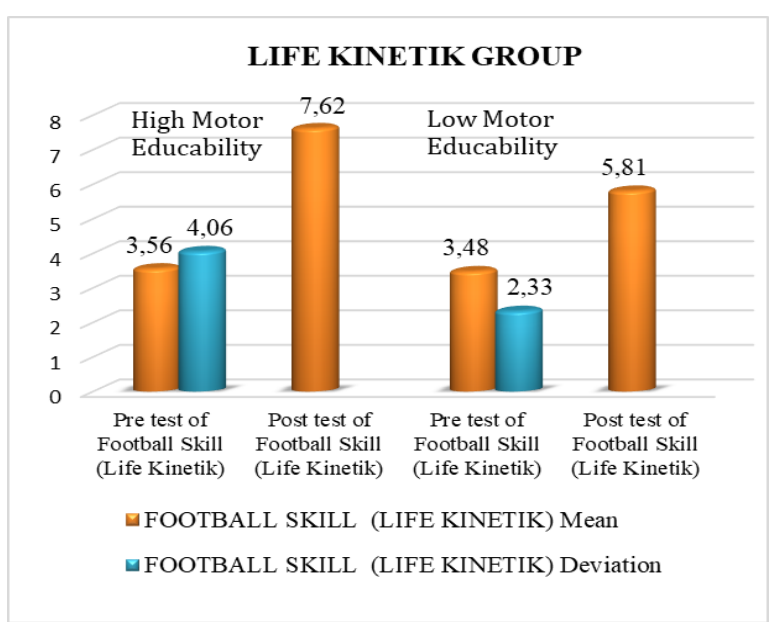

Fig. 1. Average difference in initial test score and final test in the life kinetik method training group life kinetik.

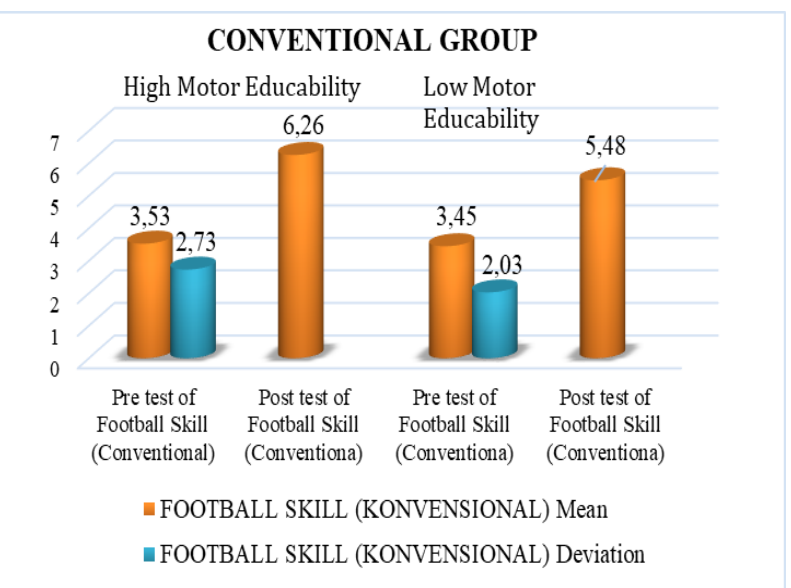

Fig. 2. Average difference in initial test score and conventional group final test.

The data collection instrument used in this study was the IOWA Brace Test Motor Instrument [15]. While the instrument to measure the performance of playing football is used GPAI

The method used in this research is the experimental method. In conducting experiments, researchers tested the Life Kinetic training method to see its effect on football playing performance, and see the effect of interaction between the two training methods with motor educability levels on soccer playing performance. The treatment is given to the sample as many as 16 meetings, twice a week which are adjusted to the characteristics of the game of football [14]. The training program provided is the Life Kinetic method and the conventional training method.

The subjects in this study were 90 male soccer athletes at the University of Indonesia Soccer UKM. Subjects who were male were aged 18 to 19 years and they actively practiced in each training session. All subjects have the right to be research subjects. The subjects used in this study were 40 people taken using simple random sampling and random selection techniques. The 40 subjects were divided into four groups through random assignment techniques.

combine three aspects of training, namely motor activity,
cognitive challenges, and visual perception. This training motor educability so that it will support mastery of motion in
motion a good concentration, coordination, and ability the sport of football. Elite junior soccer players performed period, increase in concentration, reaction speed, and error rate
change. Body coordination training has a positive influence on the brain development of children and adults, body
coordination training is training that involves complex movements, so that this exercise stimulates cells in the hippocampus, thus increasing one's memory [10].

Life Kinetic training has a significant effect on increasing concentration, motivation, and learning outcomes in tennis
skills [11]. Life Kinetic training had a significant influence on critical thinking skills, anticipation, and performance of martial achievement and cognitive function in children [13]. Based on several studies and experts' expressions that studies on motor very limited. Whereas motor educability will determine the ability to master new movements, the faster an athlete master's more and more treasury of motion which is very useful in playing football. Life Kinetic Method for athletes who have that athletes will be increasingly trained in their cognitive very well trained. Therefore, soccer athletes will be more football and playing will be more tactical. Researchers are interested in further examining the problems in this study, so the researchers gave the title in this study "the effect of the Life Kinetic training method and motor educability on improving soccer playing performance."

\section{METHOD}


TABlE I. (Two-WAy-Anova) Test of BetweEn SubJect EfFects

\begin{tabular}{|l|l|l|l|l|l|}
\hline \multicolumn{1}{|c|}{ Source } & $\begin{array}{c}\text { Type III } \\
\text { Sum of } \\
\text { Squares }\end{array}$ & df & $\begin{array}{c}\text { Mean } \\
\text { Square }\end{array}$ & F & Sig. \\
\hline Corrected Model & $327.500^{\mathrm{a}}$ & 3 & 109.167 & .623 & .605 \\
\hline Intercept & 33062.500 & 1 & 33062.500 & 188.629 & .000 \\
\hline Motor_Educability & 122.500 & 1 & 122.500 & .699 & .409 \\
\hline Method & 2.500 & 1 & 2.500 & .014 & .906 \\
\hline $\begin{array}{l}\text { Motor_Educability* } \\
\text { Method }\end{array}$ & 202.500 & 1 & 202.500 & 1.155 & .290 \\
\hline Error & 63.213 & 36 & 175.278 & & \\
\hline Total & 394.621 & 40 & & & \\
\hline Corrected Total & 64.053 & 39 & & & \\
\hline
\end{tabular}

Based on the results of ANOVA analysis calculations and the results of Tests of Between-Subjects Effects, the Corrected Model column shows that the F value obtained was .623 with a significance value of $0.605>\alpha 0.05$ then this means that $\mathrm{H} 0$ was received. These results provide an explanation that the use of both methods of training exercises does not provide a significant difference in effect on the performance of playing football. Therefore it can be concluded that: "There is no significant difference in effect between the Life Kinetic training method and the conventional training method on improving soccer playing performance". Both the Life Kinetic training method and the conventional training method have the same effect on improving the performance of playing football. The use of Life Kinetic training methods has an influence in improving the performance of playing football because the cognitive abilities of soccer players are increasing in each exercise [17]. The function of cognition is needed for performance and in daily activities, and it is important to develop cognition and development of motion, as well as social and emotional relationships throughout life [18]. By increasing the cognitive abilities experienced by football players, in a match situation the players can make decisions quickly to do something, Football is a complex sport that requires continuous movement and relies on neural mechanisms that are able to produce the right actions in a fast time [19]. Just like the Life Kinetic training method, conventional training methods also have an influence on improving soccer playing skills. In each exercise the players get various training methods given by the coach. This causes the players to get various motion experiences from the training methods provided by the coach in each meeting. The use of different methods can improve the ability of athletes in carrying out their mobile tasks [20].

Based on the ANOVA technique calculation results and the Tests of Between-Subjects Effects, the Motor Educability group and Training Method shows that the $F$ value obtained was 1,155 with a significance value of $0.290>\alpha \quad 0.05$, this means that $\mathrm{H} 0$ was received. These results provide an explanation that there is no interaction (combined effect) between motor educability and training methods. Therefore it can be concluded that: "There is no interaction between training methods with motor educability towards improving soccer playing skills". This happens because in this study most of the sample was football players who had mastered the basic techniques of playing football. The movements given during the training program run are mostly basic techniques that they have mastered before such as passing, dribbling, shooting, and others. Very few new skills are obtained by the players when running a training program. So that there is no interaction between the training methods with motor educability in improving soccer playing performance. Because motor educability is very influential on how fast a soccer player's ability is in mastering new skills [21].

Based on ANOVA technique calculations and the results of Tests of Between-Subjects Effects, the high intelligence level column shows that the $\mathrm{F}$ value obtained was .699 with a significance value of $0.409>\alpha 0.05$, so this means that $\mathrm{H} 0$ was received. These results provide an explanation that high motor educability and low motor educability have a significant influence on soccer playing skills. Therefore it can be concluded that: "There is no difference in the performance of playing football between athletes who are trained with the Life Kinetic training method and conventional training in the high motor educability group". Both players who are trained using the Life Kinetic training method and those who use conventional training methods in the high educability motorbike group have the same performance improvement in playing football. But in the Life Kinetic training method groups the application of training forms is more quickly mastered because with a high level of motor educability the players will be easier and faster in mastering a new movement [21]. Because in Life Kinetic training there are extraordinary combinations of limb movements such as capturing, throwing objects, visual perception exercises, and coordination of eyes and limbs, which are fundamental characteristics of Life Kinetic exercises [14].

Furthermore, to find out the High and Low motor educability groups using two training methods that have a better impact can be seen and listed in Table 3.2. Motor Educability Level and Exercise Method.

TABLE II. Results AVERAge VAlue of Motor EduCABILITy with TRAINING METHODS

\begin{tabular}{|l|l|l|c|c|c|}
\hline \multicolumn{2}{|c|}{ Dependent Variable: Learning Results for Playing Football Skills } \\
\hline $\begin{array}{c}\text { Motor } \\
\text { Educability }\end{array}$ & $\begin{array}{c}\text { Training } \\
\text { Method }\end{array}$ & Mean & $\begin{array}{c}\text { Std. } \\
\text { Error }\end{array}$ & $\begin{array}{c}\text { 95\% Confidence } \\
\text { Interval }\end{array}$ \\
\hline \multicolumn{3}{|c|}{} & $\begin{array}{c}\text { Lower } \\
\text { bound }\end{array}$ & $\begin{array}{c}\text { Upper } \\
\text { Bound }\end{array}$ \\
\hline $\begin{array}{l}\text { High Motor } \\
\text { Educability }\end{array}$ & Life Kinetik & 33.000 & 4.187 & 24.509 & 41.491 \\
\cline { 2 - 7 } & Conventional & 28.000 & 4.187 & 19.509 & 36.491 \\
\hline $\begin{array}{l}\text { Low Motor } \\
\text { Educability }\end{array}$ & Life Kinetik & 25.000 & 4.187 & 16.509 & 33.491 \\
\cline { 2 - 7 } & Convensional & 29.000 & 4.187 & 20.509 & 37.491 \\
\hline
\end{tabular}

The table above shows that the Mean value that distinguishes the influence is greater or more dominant by comparing the average results in the table. There was no significant difference in the improvement in performance in playing football between athletes trained with the Life Kinetic training method and conventional training in the low motor educability group. Just as in the group of high motor educability, the two training methods had an influence on improving the performance of playing football. There is no difference in influence over the ability of the players who are sampled in this study are the players who have mastered the skills to play soccer well. Even though their level of motor 
education is at a low level, their ability to master the basic techniques of playing football is at a good level. So the level of motor educability does not have an effect on their ability because there is no new movement they do in playing football. The ability of motor educability will greatly affect how fast a soccer player's ability is in mastering new skills [21]. However, the application of training with the Life Kinetic method of the low motor educability group requires a longer time to do each form of exercise. Because the players will be given a combination of different motion activities (especially in basic motion techniques which are often problematic in making movements and forming relationships with the cortex, increasing the efficiency of motion throughout the training process carried out by athletes. These exercises not only form motion techniques but activate them from initial movement to the most important motion [22].

\section{CONCLUSION}

Based on the results of the study it can be concluded that: First: there is no significant difference in effect between the Life Kinetic training method and the conventional training method on improving soccer playing performance. Second; there is no interaction between training methods with motor educability on improving soccer playing performance. Third: there is no difference in performance improvement in playing football between athletes who are trained with the Life Kinetic training method and conventional training in the high motor educability group. Fourth: there is no difference in the improvement in performance in playing football between athletes trained with the Life Kinetic training method and conventional training in the low motor educability group.

\section{REFERENCES}

[1] B. Omosegaard, Physical Training for Badminton. Denmark: Bo Omosegaard and Malling Beck Publisher, 2005.

[2] Thomas and Over, "Psychological and psychomotor skill associated with performance in golf," The sport psychologist, vol. 8, pp. 37-86, 1994.

[3] Komarudin, Psikologi Olahraga: Latihan Mental dalam Olahraga Kompetitif. Bandung: Rosdakarya, 2016.

[4] Harsono, Periodisasi Program Pelatihan. Bandung: Rosdakarya, 2015.

[5] Waldemar Winkler, "Motor Skills and Cognitive Training for Junior Soccer Players," International Journal of Performance Analysis In Sport, vol. 1(1), pp. 91-105, 2017.
[6] R..M. Agustyananto, Mengapa pesepakbola Indonesia terlalu takut untuk berkarir di luar Indonesia, August 2015, published, retrieved from: http//:fourfourtwo.com.

[7] J.D. Clements and C.D, "Botterill, Goal setting in shaping of future Performance of athletes," in: Coach, athlete and sport psychologist, 1st ed., Toronto: Canada Human Kinetiks Publishers, 1979, pp. 199.

[8] McCloy, "A Preliminary Study of Factors in Motor educability," American Association for Health, Physical Education and Recreation, vol. 11(2), pp. 28-39, 2013.

[9] Biesen, Van Debbie, Lore Jacobs, Katina McCulloch, Luc Janssens and Yves C Vanlandewijck, "Cognitive Motor Dual Task Ability of Athletes with and without Intellectual Impairment," Journal of Sport Sciences, 2017.

[10] Matthias Grünke, Life Kinetik Exercise. Cologne University. By Life Kinetik, 2014.

[11] Komarudin, Pelatihan Brain Jogging untuk meningkatkan konsentrasi, motivasi, dan hasil belajar keterampilan tenis. Hibah PPKBK UPI tahun 2016.

[12] Mulyana, Pengaruh pelatihan Life Kinetik terhadap berpikir kritis, antisipasi, koordinasi, dan performa atlet pencak silat. Hibah PPKBK UPI tahun 2016.

[13] M.D. Hoyo, "Effects of 10-week eccentric overload training on kinetik parameters during change of direction in football players." Science and Medicine in Football, Journal of Sports Sciences, vol. 34(14).

[14] Demirakca, et al,. The Exercising Brain: Changes in Functional Connectivity Induced by an Integrated Multimodal Cognitive and Whole-Body Coordination Training. Hindawi Publishing Corporation Neural Plasticity, 2016.

[15] L. Hatlestad, (2013). Motor educability tests for women college students. Research

[16] D. Memmert, "The Game Performance Assessment Instrument (GPAI): Some Concernsand Solutions for Further Development," Journal of Teaching in Physical Education, vol. 27, pp. 220-240, 2008.

[17] Masley, et al., "Influence Of Aerobic Exercise On Inhibitory Control Of Excutive Function In Spastic Hemiplegic Cerebral Palsy: A Randomized Controlled Trail," Journal of Clinical Psychology in Medical Settings June 2009, vol. 16(2), pp. 186-193, 2009.

[18] Moffitt, et al., "A gradient of childhood self-control predicts health, wealth, and public safety," PNAS February 15, vol. 108(7), pp. 26932698, 2011.

[19] D.V. Buonomano and R. Laje, Population clocks: motor timing with neural dynamics," Trends Cogn. Sci, vol. 14, pp, 520-527, 2010.

[20] D. Baker, Improving vertical jump performance through general, special, and specific strength training," J. Strength Cond. Res, vol. 10, pp. 131-136, 1996.

[21] Rusli Lutan, Strategi Belajar Mengajar Pendidikan Jasmani dan. Kesehatan. Jakarta: Departemen Pendidikan Nasional, Direktorat Jenderal, 2000.

[22] H. Duda, "Application of Life Kinetik in the process of teaching technical activities to young football players," vol. 25(71), 2015, retrieved from: http://e-antropomotoryka (2015). 